OPEN ACCESS

Edited by:

Jan-Ake Gustafsson,

University of Houston, United States

Reviewed by:

Jonathan Bogan,

Yale University, United States

Andrew C. B. Cato,

Karlsruhe Institute of Technology,

Germany

*Correspondence:

Ana Carolina Migliorini Figueira ana.figueira@Inbio.cnpem.br

Specialty section:

This article was submitted to Molecular and Structural

Endocrinology,

a section of the journal

Frontiers in Endocrinology

Received: 29 October 2017 Accepted: 11 January 2018 Published: 01 February 2018

Citation:

Ribeiro Filho HV, Bernardi Videira N, Bridi AV, Tittanegro TH,

Helena Batista FA,

de Carvalho Pereira JG,

de Oliveira PSL, Bajgelman MC, Le Maire A and Figueira ACM (2018)

Screening for PPAR Non-Agonist Ligands Followed by Characterization

of a Hit, AM-879, with Additional

No-Adipogenic and cdk5-Mediated Phosphorylation Inhibition Properties.

Front. Endocrinol. 9:11.

doi: 10.3389/fendo.2018.00011

\section{Screening for PPAR Non-Agonist Ligands Followed by Characterization of a Hit, AM-879, with Additional No-Adipogenic and cdk5-Mediated Phosphorylation Inhibition Properties}

Helder Veras Ribeiro Filho ${ }^{1,2}$, Natália Bernardi Videira ${ }^{1,2}$, Aline Villanova Bridi², Thais Helena Tittanegro ${ }^{1,2}$, Fernanda Aparecida Helena Batista', José Geraldo de Carvalho Pereira', Paulo Sérgio Lopes de Oliveira', Marcio Chaim Bajgelman', Albane Le Maire ${ }^{1,3}$ and Ana Carolina Migliorini Figueira ${ }^{1,2 *}$

\begin{abstract}
${ }^{1}$ Brazilian Biosciences National Laboratory (LNBio), Brazilian Center for Research in Energy and Materials (CNPEM), Campinas, Brazil, ${ }^{2}$ Post Graduation Program in Biosciences and Technology of Bioactive Products, Institute of Biology, University of Campinas (UNICAMP), Campinas, Brazil, ${ }^{3}$ Centre de Biochimie Structurale CNRS, Université de Montpellier, Montpellier, France
\end{abstract}

Peroxisome proliferator-activated receptor gamma (PPAR $\gamma$ ) is a member of a nuclear receptor superfamily and acts as a ligand-dependent transcription factor, playing key roles in maintenance of adipose tissue and in regulation of glucose and lipid homeostasis. This receptor is the target of thiazolidinediones, a class of antidiabetic drugs, which improve insulin sensitization and regulate glycemia in type 2 diabetes. Despite the beneficial effects of drugs, such as rosiglitazone and pioglitazone, their use is associated with several side effects, including weight gain, heart failure, and liver disease, since these drugs induce full activation of the receptor. By contrast, a promising activation-independent mechanism that involves the inhibition of cyclin-dependent kinase 5 (CDK5)-mediated PPAR $\gamma$ phosphorylation has been related to the insulin-sensitizing effects induced by these drugs. Thus, we aimed to identify novel PPARy ligands that do not possess agonist properties by conducting a mini-trial with 80 compounds using the sequential steps of thermal shift assay, 8-anilino-1-naphthalenesulfonic acid fluorescence quenching, and a cell-based transactivation assay. We identified two non-agonist PPARy ligands, AM-879 and P11, and one partial-agonist, R32. Using fluorescence anisotropy, we show that AM-879 does not dissociate the NCOR corepressor in vitro, and it has only a small effect on TRAP coactivator recruitment. In cells, AM-879 could not induce adipocyte differentiation or positively regulate the expression of genes associated with adipogenesis. In addition, AM-879 inhibited CDK5-mediated phosphorylation of PPAR in vitro. Taken together, these findings supported an interaction between AM-879 and PPAR $\gamma$; this interaction was identified by the analysis of the crystal structure of the PPARy:AM-879 complex and evidenced by AM-879's mechanism of action as a putative 
PPARy non-agonist with antidiabetic properties. Moreover, we present an optimized assay pipeline capable of detecting ligands that physically bind to PPAR $\gamma$ but do not cause its activation as a new strategy to identify ligands for this nuclear receptor.

Keywords: peroxisome proliferator activator receptor $\gamma$, diabetes, adipogenesis, ligand screening pipeline, nonagonist

\section{INTRODUCTION}

Obesity and type 2 diabetes are characteristic pathologies of the metabolic syndrome and have reached epidemic proportions in recent years (1). They are associated with an increased risk of cardiovascular disease and stroke. Obesity and type 2 diabetes may be defined as accumulation of excessive body fat that impairs health and longevity and as a chronic metabolic disorder that results partly in the inability of the body to respond adequately to circulating insulin, respectively (2). Recent studies have improved our knowledge about these conditions and have suggested that adipose tissue is at the center of the metabolic syndrome (3). Other reports have shown that peroxisome proliferator-activated receptor gamma (PPAR $\gamma$ ) plays key roles in adipose tissue, acting as a master regulator of fat cell biology (4-6). Perhaps, the most clinically relevant finding in this field was the now well-established link between PPAR $\gamma$ activity and insulin sensitivity (7).

Peroxisome proliferator-activated receptor gamma is a member of a nuclear receptor superfamily and acts as a ligand-dependent transcription factor. Endogenously, PPAR $\gamma$ is modulated by various fatty acid (FAs) and their metabolites, playing roles in glucose and lipid homeostasis $(6,8-10)$. To exert its biological effects, PPAR $\gamma$ depends on ligand binding, which induces conformational changes in the receptor's structure that lead to a dynamic process of corepressor dissociation and coactivator recruitment (11). Through this process, $\operatorname{PPAR} \gamma$ activates the transcriptional machinery and regulates the expression of genes involved in several metabolic processes, such as adipocyte differentiation (12, 13) and insulin sensitivity $(14,15)$.

In this context, PPAR $\gamma$ is the target of thiazolidinediones (TZD), a class of antidiabetic drugs, that improve insulin sensitization and regulate glycemia in type 2 diabetes (16-18). However, despite their beneficial antidiabetic effects, TZD drugs, such as rosiglitazone (Rosi) and pioglitazone, have been associated with several side effects, including weight gain, heart failure, and liver disease, which have restricted the use of these drugs (19-22). In fact, PPAR $\gamma$ activation by TZDs results in dysregulation of the expression of several genes involved in metabolic processes, such as adipogenesis; this dysregulation leads to the undesired side effects. In 2010, Choi and coworkers showed that the insulinsensitizing effects produced by TZDs were a consequence of the inhibition of cyclin-dependent kinase 5 (CDK5)-mediated PPAR $\gamma$ phosphorylation at serine 273 (or S245 in PPAR $\gamma 1$; the

\footnotetext{
Abbreviations: $\operatorname{PPAR} \gamma$, peroxisome proliferator activator receptor $\gamma ; \mathrm{LBD}$, ligandbinding domain; ANS, 8-Anilino-1-naphthalenesulfonic acid; DMSO, dimethyl sulfoxide; FA, fatty acid; Kd, dissociation constant; LBD, ligand-binding domain; Rosi, rosiglitazone; Tm, melting temperature; TSA, thermal shift assay; TZD, thiazolidinediones.
}

phosphorylation site in PPAR $\gamma 2$ differs from that in PPAR $\gamma 1$ by an additional 28-residue sequence in the $\mathrm{N}$-terminal), rather than the effect of PPAR $\gamma$ activation by these drugs. Accordingly, significant research effort has been made to find selective ligands that modulate PPAR $\gamma$, promoting its minimum activation and maintaining its positive antidiabetic properties. In this context, the development of PPAR $\gamma$ partial- and non-agonists is a promising strategy for diabetes management.

Hitherto, several screening pipelines have been designed to search for novel PPAR $\gamma$ ligands (23-25). Transactivation assays and combined approaches using transactivation and binding assays are the best-established and used methods to screen for compounds that activate PPAR $\gamma(26,27)$. However, only a restricted number of screening techniques have been designed and applied to find PPAR $\gamma$ non-agonists $(28,29)$. Thus, in the present study, we developed a screening pipeline to identify ligands capable of interacting with PPAR $\gamma$ but that lack the activation properties ascribed to its full agonists; the pipeline developed was based on previously reported approaches $(29,30)$. Moreover, we characterized a previously identified compound, AM-879 (29), as a putative PPAR $\gamma$ non-agonist, describing in detail its mechanism of action. AM-879 did not exhibit adipogenic properties and could inhibit CDK5-mediated phosphorylation of PPAR $\gamma$.

\section{MATERIALS AND METHODS}

\section{Screening Compounds Selection}

A library of 80 compounds composed of different classes of molecules, including sulfonamides, sulfonylureas, hydrazones, chalcones, and TZD, was used for PPAR $\gamma$ ligand screening. This mini-library was composed by 67 compounds, which previously had presented some antidiabetic properties in mice (personal communication), and that were synthesized and generously gifted by Prof. Dr. Ricardo José Nunes and Prof. Dr. Rosendo Augusto Yunes from UFSC (Brazil); one compound gifted by the Laboratory of Chemistry and Natural Products (LQPN, LNbio/CNPEM, Brazil); six gifted by Prof. Dr. Ronaldo Aloise Pilli from UNICAMP (Brazil), and six commercial compounds, which includes the already described PPAR $\gamma$ ligand, AM-879 (4-(\{2-[(1,3-dioxo-1,3-dihydro-2H-inden-2-ylidene) methyl] phenoxy\} methyl) benzoic acid, AM-879-40965082, Specs).

\section{PPAR $\gamma$ Expression, Purification, and Biophysical Characterization}

Peroxisome proliferator-activated receptor gamma ligand-binding domain (LBD) construction (isoform PPAR $\gamma 1$ ), encoding AAs 207-477, inserted in pET 28a (+), was expressed in Escherichia coli strain BL21 (DE3). Cells were growth in $\mathrm{LB}$, at $22^{\circ} \mathrm{C}$, until 
$\mathrm{OD}_{600 \mathrm{~nm}}$ reached 0.8 , and were induced with $1 \mathrm{mM}$ Isopropyl $\beta$-D-1-thiogalactopyranoside (IPTG) for $16 \mathrm{~h}$. After this, bacteria were harvested by centrifugation $(16,000 \mathrm{rcf})$, and the pellet was resuspended in lysis buffer $(50 \mathrm{mM}$ Tris- $\mathrm{HCl} \mathrm{pH} 8.0,300 \mathrm{mM}$ $\mathrm{NaCl}, 5 \%$ glycerol, $2 \mathrm{mM} \beta$-mercaptoethanol, $0.1 \mathrm{mM}$ PMSF, $1 \mathrm{mg}$ lysozyme). The extract was sonicated on ice bath and the soluble fraction was separated by centrifugation at 36,000 rcf, for $40 \mathrm{~min}$, at $4^{\circ} \mathrm{C}$, in Avanti J26xPT (Beckman Coulter, rotor JA-2550). Purification was performed by affinity chromatography using a Talon Superflow resin (Clontech), the protein was eluted in $50 \mathrm{mM}$ Tris- $\mathrm{HCl}$ pH 8.0, $300 \mathrm{mM} \mathrm{NaCl}, 5 \%$ glycerol, $300 \mathrm{mM}$ imidazole and $2 \mathrm{mM} \beta$-mercaptoethanol, and submitted to a size exclusion chromatography through a Hiload Superdex 200 16/60 (GE life sciences), following the manufacturer's instruction, to improve purity and remove imidazole. Samples purity was checked by SDS-PAGE and protein concentration was measured through nanodrop (ThermoScientific). For crystallization, purified PPAR $\gamma$ LBD (construction 197-477) was concentrated to $8.5 \mathrm{mg} / \mathrm{ml}$ in a buffer containing $20 \mathrm{mM}$ Tris- $\mathrm{HCl}, \mathrm{pH} 8.5$, $250 \mathrm{mM} \mathrm{NaCl}, 5 \mathrm{mM}$ dithiothreitol, and $1 \mathrm{mM}$ EDTA.

Sample aggregation, monodispersity and oligomeric state were evaluated after protein purification by performing dynamic light scattering (DLS), native electrophoresis (NG), and circular dichroism (CD) measurements (Figure S1 in Supplementary Material). DLS measurements were obtained in Protein Solutions DynaPro DLS system (Wyatt), with 50 accumulations of $2.5 \mathrm{~s}$, at $10^{\circ} \mathrm{C}$. The NG was performed in phast system (GE Life Sciences), using $8-25 \%$ acrylamide gradient phast gels, following the manufacturer's manual. Far-UV CD measurements were performed on a Jasco J-810 Spectropolarimeter coupling to a peltier control, in $1 \mathrm{~mm}$ Quartz cuvettes (Hellma) and protein samples $(5 \mu \mathrm{M})$ were dialyzed to remove salt excess in Slide-A-Lyzer ${ }^{\circledR}$ Mini Dialysis Units tubes 10,000 MWCO, for $16 \mathrm{~h}$. The spectra were recorded from 190 to $260 \mathrm{~nm}$, at $10^{\circ} \mathrm{C}$, using a $50 \mathrm{~nm} / \mathrm{min}$ scan speed and 20 accumulations.

\section{Thermal Shift Assay (TSA)}

Protein thermal unfolding was monitored by measuring the SYPRO $^{\circledR}$ Orange probe (Life technologies) fluorescence. PPAR $\gamma$ samples $(4 \mu \mathrm{M})$ were incubated with threefold ligand excess $(12 \mu \mathrm{M})$ and SYPRO Orange, in a reaction volume of $25 \mu \mathrm{L}$. Rosi was used as aPAR $\gamma$ full agonist control and, dimethyl sulfoxide (DMSO), as apo-PPAR $\gamma$ control. TSA was performed in triplicates, in 96-well PCR microplates (Applied Biosystems-Life Technologies), through an RT-PCR device (7500 Real Time PCR System). Samples were heated at $1^{\circ} \mathrm{C}$ per min, from 10 to $90^{\circ} \mathrm{C}$. Fluorescence intensities were plotted as a function of temperature and, the melting temperature ( $\mathrm{Tm}$ ) of the protein unfolding transition was obtained through a Boltzmann model in Origin Pro 8.1 and using an Excel based worksheet (DSF Analysis v3.0.2, ftp:// ftp.sgc.ox.ac.uk/pub/biophysics).

\section{NanoDSF}

Intrinsic tryptophan and tyrosine fluorescence were measured using NT48 device (NanoTemper), as a more sensitive technology to check protein stability in comparison to TSA. Capillaries were filled with $10 \mu \mathrm{L}$ of PPAR $\gamma(25 \mu \mathrm{M})$, pre-incubated with DMSO or ligands ( $75 \mu \mathrm{M}, 3 \mathrm{M}$ excess) for $1 \mathrm{~h}$, on ice. The initial fluorescence scan of loaded capillaries was performed at $20^{\circ} \mathrm{C}$, monitoring emission wavelength at 330 and $350 \mathrm{~nm}$ in order to find the optimal signal range. After this step, samples were subjected to a temperature ramp of $1^{\circ} \mathrm{C} / \mathrm{min}$ from 20 to $90^{\circ} \mathrm{C}$ and fluorescence was constantly monitored. Data were analyzed and Tm was determined using PR. ThermControl software (NanoTemper).

\section{8-Anilino-1-Naphthalenesulfonic Acid (ANS) Fluorescence Quenching}

8-Anilino-1-naphthalenesulfonic acid fluorescence quenching assay was performed incubating $1 \mu \mathrm{M}$ of PPAR $\gamma$ with $10 \mu \mathrm{M}$ of the fluorescent probe ANS for $30 \mathrm{~min}$. Following this, increasing concentrations $(0.1-60 \mu \mathrm{M})$ of the pre-selected 20 compounds were titrated in protein-ANS solution. The fluorescence measurements were taken on a EnSpire multimode plate reader (Perkin Elmer) through a 96-well all-black-walled plate (Perkin Elmer), with excitation wavelength set at $380 \mathrm{~nm}$ and emission wavelength range of $400-600 \mathrm{~nm}$, at $25^{\circ} \mathrm{C}$. Fluorescence emission at the wavelength of maximum intensity $(475 \mathrm{~nm})$ was monitored for each concentration of compounds. Fluorescence data were fitted to binding curves using Hill model for dissociation constant (Kd) calculation. All experiments were performed in triplicates and data were processed using the software Origin Pro 8.1.

\section{Cell Transactivation Assay}

293T (ATCC ${ }^{\circledR}$ CRL-3216 ${ }^{\mathrm{TM}}$ ) cells were cultured in Dulbecco's Modified Eagle's Medium (DMEM, Gibco ${ }^{\circledR}$ ) supplemented with $10 \%(\mathrm{v} / \mathrm{v}$ ) fetal bovine serum, $50 \mathrm{U} / \mathrm{mL}$ penicillin, and $50 \mathrm{mg} / \mathrm{mL}$ streptomycin, at $37^{\circ} \mathrm{C}$, and humidified atmosphere of $5 \% \mathrm{CO}_{2}$. For transactivation assays, cells were seeded in 24 -well plates (density of $2.0 \times 10^{5}$ cells/well), and transiently transfected with Lipofectamine $^{\circledR} 2000$ (Invitrogen) and $0.5 \mu \mathrm{g}$ of the following plasmids: pRL-TK, a transfection control, which express Renilla reniformis luciferase constitutively; pGRE-LUC, which contains responsive element for GAL4 protein followed by reporter gene of firefly luciferase; $\mathrm{pBIND}-\mathrm{PPAR} \gamma$, a chimeric protein composed by GAL4-DBD and PPAR $\gamma$-LBD, under control of the cytomegalovirus promoter (CMV), in a proportion of $1.5 \mu \mathrm{g}$ DNA: $2 \mu \mathrm{L}$ of Lipofectamine. As negative control, empty BlueScript plasmid was used instead of pBIND-PPAR $\gamma$. For isotype specificity transactivation assay, cells were seeded in 96-well plates (density of $4.0 \times 10^{4}$ cells/well) and transfected with pRL-TK; pGRE-LUC and pBIND-PPAR $\alpha$; and pBIND-PPAR $\beta$.

Four hours after transfection, the culture medium was exchanged to DMEM plus 10\% FBS Charcoal stripped broth and $1 \mu \mathrm{M}$ of each tested compound, Rosi or $1 \%$ DMSO was added to each well. In dose-response experiments, concentration of compounds was increased from 0.01 to $0.1 \mathrm{mM}$. After $24 \mathrm{~h}$ of treatment, reporter gene expression was measured with Dual-Luciferase $^{\circledR}$ Reporter (DLR ${ }^{\mathrm{TM}}$ ) Assay System (Promega), according to manufacturer's instructions in a GloMaxMulti + Detection System (Promega). Average curves were fitted applying Boltzmann function until fitting converges with a software tolerance criterion using Origin software (version 8.0, OriginLab Corporation). 


\section{In Vitro Coregulators Recruitment}

Apo-PPAR $\gamma$ or PPAR $\gamma$ in the presence of $3 \mathrm{M}$ excess of Rosi (positive control), P11 or AM-879, in concentration that varies from 0.004 to $20 \mu \mathrm{M}$ was incubated with $20 \mathrm{nM}$ of fluorescein labeled TRAP peptide (ID2) or NCoR peptide (ID2). These mixtures were submitted to fluorescence anisotropy measurements using ClarioStar $^{\circledR}$ plate reader (BMG), with emission and excitation filters adjusted for fluorescein. Kd were obtained from fluorescence data fitted to binding curves using Hill model (Figure S4 in Supplementary Material). Data from experiment done in triplicate were compared by the one-way ANOVA followed by Bonferroni's multiple comparison test using GraphPad Prism.

\section{Adipocyte Differentiation Assay}

3T3-L1 (ATCC ${ }^{\circledR}$ CRL-3242 ${ }^{\mathrm{TM}}$ ) cells were cultured in DMEM $\left(\mathrm{Gibco}^{\circledR}\right)$ supplemented with $10 \%$ (v/v) fetal bovine serum, $50 \mathrm{U} /$ $\mathrm{mL}$ penicillin, and $50 \mathrm{mg} / \mathrm{mL}$ streptomycin, at $37^{\circ} \mathrm{C}$, and humidified atmosphere of $5 \% \mathrm{CO}_{2}$. After achieved $70 \%$ confluency, cells were trypsinized and seeded in 6-well plates (Corning) at a density of $2.8 \times 10^{5}$ cells/well. After 2 days, cells were treated with dexamethasone $(1 \mathrm{mM})$ to induce preadipocytes differentiation, and $1 \mu \mathrm{M}$ of Rosi, $1 \mu \mathrm{M}$ of AM-879, or 1\% DMSO. After treatment, the culture medium was exchanged every $48 \mathrm{~h}$, supplemented with $1 \mu \mathrm{M}$ of each ligand, for 6 days. In order to measure adipocyte differentiation, fully differentiated 3T3-L1 cells were washed with phosphate-buffered saline (PBS), fixed with $10 \%$ formalin (v/v) for $1 \mathrm{~h}$, and then, stained with oil red solution (Oil Red O) $(0.3 \%$ in isopropanol 60\%) for $20 \mathrm{~min}$. After staining, cells were washed with PBS and photographed in Nikon MTS microscope (Nikon). Lipid accumulation was also quantified by Oil Red $\mathrm{O}$ absorbance measurement at $520 \mathrm{~nm}$. For this measurement, cells lysis was performed in $200 \mu \mathrm{L}$ of isopropanol and $4 \%$ Igepal solution, and the absorbance of the samples was recorded in a $10-\mathrm{mm}$ cuvette in a spectrophotometer (V-530, Jasco). Data were compared using unpaired $t$-test.

\section{Gene Expression Analysis}

Total RNA from differentiated 3T3-L1 cells was extracted by RNeasy kit (Qiagen) and cDNAs were synthesized with HighCapacity cDNA Reverse Transcription Kit (ThermoFischer Scientific). Quantitative PCR reactions were performed with SYBR Real Time PCR master mixes (ThermoFischer Scientific) and $50 \mathrm{ng}$ of cDNA, in a 7500 Real Time PCR system (Applied Biosystems). Relative mRNA expression was determined by the $\Delta \Delta$-Ct method normalized to GAPDH levels. The sequences of primers used in this study are presented in Table S2 in Supplementary Material.

\section{In Vitro Phosphorylation Assay}

Peroxisome proliferator-activated receptor gamma phosphorylation mediated by CDK5 at serine 273 was measured byluminescent detection of ADP produced in a in vitro phosphorylation reaction. Purified PPAR $\gamma$ LBD $(1.2 \mu \mathrm{M})$ was previously pre-incubated with $5 \mathrm{M}$ excess of Rosi, AM-879 or DMSO, for $30 \mathrm{~min}$, at $4^{\circ} \mathrm{C}$. Then, protein and ligands were incubated with $50 \mathrm{ng}$ CDK5/p35 (Sigma), for $1 \mathrm{~h}$, at room temperature, in the CDK5/p35 reaction buffer (composition recommended by manufacturer) and in the presence of ATP $10 \mu \mathrm{M}$. After reaction, ADP detection was performed by using ADP-Glo ${ }^{\mathrm{TM}}$ kinase assay (Promega) following manufacturer's instructions. Luminesce signal was recorded using GloMax-Multi + Detection System (Promega) microplate luminometer.

\section{Crystallization, Crystallographic Data Collection, Processing, and Structure Refinement}

Crystallization was performed as described in Ref. (31). Crystals were obtained by co-crystallization, mixing $1 \mu \mathrm{L}$ protein solution (8.5 mg/mL PPAR $\gamma$ LBD), $1 \mu \mathrm{L}$ well solution (0.9 M trisodium citrate, $100 \mathrm{mM}$ HEPES, $\mathrm{pH}$ 7.0, 3.5\% 1,2-propanediol) and AM-879 in a molar ratio of 1:4 (protein:ligand) in the drop. After 2-3 days crystals appeared and, within a few days, grew to $150-200 \mu \mathrm{m}$. Before diffraction data collection, crystals were transferred to a cryoprotectant containing $20 \%$ glycerol in well solution, supplemented with fourfold excess ligand, and frozen in liquid nitrogen. Diffraction data were collected at the MX2 beamline from the Laboratorio Nacional de Luz Sincrotron (LNLS, Campinas, Brazil). Diffraction data were processed using XDS (32). Structures were solved by using the previously reported structure 3PBA (33) from which the ligand was omitted. The calculation of POLDER map (34) was necessary to position the ligand into the electron density. The structure was modeled with COOT (35) and refined in phenix.refine from the PHENIX program suite (36). The atomic coordinates have been deposited in the Protein Data Bank under the accession code 6AN1.

\section{RESULTS}

\section{Structure Stabilization As a First Tool for PPAR $\gamma$ Ligand Search}

Ligand-bound PPAR $\gamma$ presents a higher structural stability than the unbound receptor $(37,38)$; therefore, the first step in our ligand screening involved searching for molecules that increased the stability of PPAR $\gamma$ using a TSA. Tms obtained for PPAR $\gamma$ in the presence of each compound are shown in Figure 1. Apo-PPAR $\gamma$ presented a Tm of $48.75 \pm 0.08^{\circ} \mathrm{C}$ (lower line), while in the presence of Rosi, the Tm shifted to $49.71 \pm 0.05^{\circ} \mathrm{C}$ (upper line). Among all the 80 tested compounds, we selected 20 that presented the most significant increases in Tm (gray circles in Figure 1). These molecules promoted the receptor tertiary structure stabilization, presumably by binding to PPAR $\gamma$; therefore, they were chosen for further investigation in our proposed pipeline.

\section{Measurements of Direct Binding to Three Possible Selected Ligands for PPAR $\gamma$}

A PPAR $\gamma$ ligand-binding assay was employed as the second step of the pipeline; this assay was based on the fluorescence quenching of ANS. The ANS probe interacts with the PPAR $\gamma$ binding pocket (30); therefore, the fluorescence quenching observed after titration of a compound is a consequence of the successful competition the compound and the ANS probe in the receptor 


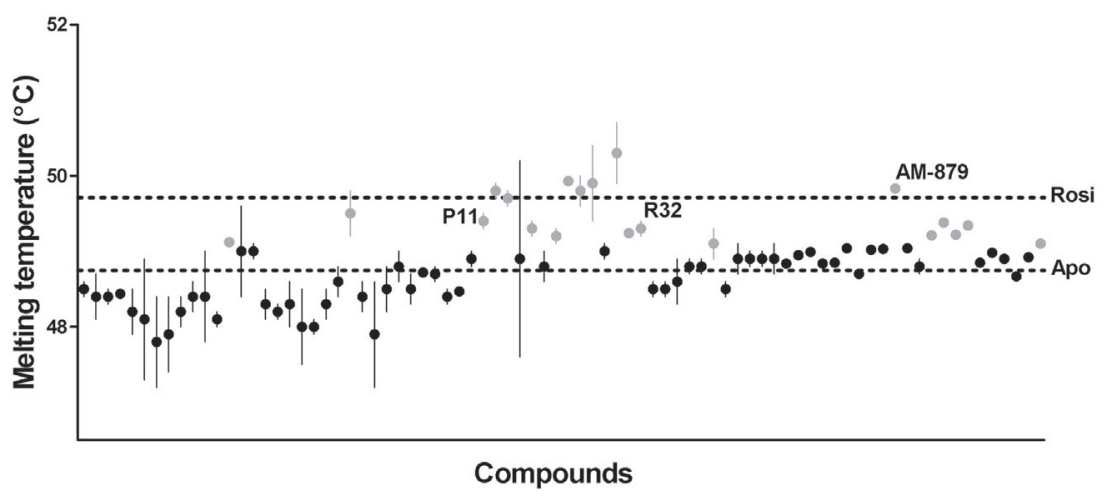

FIGURE 1 | Melting temperature of peroxisome proliferator-activated receptor gamma (PPAR $\gamma$ ) obtained by thermal shift assay (TSA) in the presence of 80 screened compounds. Upper dashed line marks the melting temperature (Tm) of PPARy in presence of Rosiglitazone (Rosi; positive control) and the lower dashed line marks the Tm of apo-PPAR (negative control). Gray circles represent the 20 selected compounds with highest Tm, and the black circles correspond to the unselected compounds. Tm of the three ligands selected at the end of screening are indicated by their names P11, R32, and AM-879. thermal shift assay was performed in triplicates in three independent experiments, errors bars represent SEM.

ligand-binding pocket (LBP), suggesting that the compound effectively binds to PPAR $\gamma$.

From the 20 compounds pre-selected by the TSA, we identified three that significantly decreased the ANS fluorescence intensity in a concentration-dependent manner; this concentrationdependent decrease is also observed on treatment with Rosi (Figure S2 in Supplementary Material). Compound AM-879, and two chalcones, P11 and R32 (Figure 2A), showed total suppression of the fluorescence signal and a reasonable affinity for the receptor binding site (Figure $\mathbf{2 C}$ ).

Analysis of the fluorescence intensities at $475 \mathrm{~nm}$ vs the ligand concentration confirmed that Rosi had the highest affinity for PPAR $\gamma$, with a Kd of $0.4 \pm 0.1 \mu \mathrm{M}$, while AM-879 and P11 showed moderate affinities (Kd values of $4.5 \pm 0.6$ and $3.3 \pm 0.7 \mu \mathrm{M}$, respectively). Among the selected compounds, R32 exhibited the lowest affinity for PPAR $\gamma(\mathrm{Kd}$ of $15.7 \pm 2.7 \mu \mathrm{M}$ ) (Figures 2B,C).

In addition, we employed a nano differential scanning fluorimetry (nanoDSF) assay to confirm the stability of the structure when these three ligands bind PPAR $\gamma$ (Table S1 in Supplementary Material). The Tms obtained by nanoDSF maintained the same order for the tested ligands as that obtained by TSA. A higher Tm $\left(49.9 \pm 0.027^{\circ} \mathrm{C}\right)$ was induced by Rosi, followed by the ligands AM-879 $\left(48.8 \pm 0.114^{\circ} \mathrm{C}\right)$ and $\mathrm{P} 11\left(48.0 \pm 0.172^{\circ} \mathrm{C}\right)$. The difference between the PPAR $\gamma \mathrm{Tm}$ in the presence of DMSO and in the presence of Rosi was $2.6^{\circ} \mathrm{C}$. Thus, we confirmed the binding of AM-879, P11, and R32 to PPAR $\gamma$ ligand-binding domain (LBD) in the micromolar range; therefore, we further characterized the effects of these molecules on PPAR $\gamma$ activation.

\section{Transactivation Assay Shows No PPAR $\gamma$ Activation by AM-879 and P11 but a Slight Activation by R32}

To identify compounds that bind to PPAR $\gamma$ and bring about minimal activation of this receptor, we performed a transactivation assay in 293T cells as the last step of our pipeline. ANS and TSA assays showed that AM-879, P11, and R32 have lower affinity for PPAR $\gamma$ than Rosi; therefore, we verified whether increasing concentrations of these compounds could induce activation of PPAR $\gamma$ in a concentration-dependent manner. The dose-response curves shown in Figure 3 indicated that Rosi activated PPAR $\gamma$ the most, with an $\mathrm{EC}_{50}$ of $2.39 \pm 0.01 \mu \mathrm{M}$, while AM-879 and P11 did not activate PPAR $\gamma$ even at the highest concentration. By contrast, compound R32 showed slight activation at concentrations above $1 \mu \mathrm{M}$, with an $\mathrm{EC}_{50}$ of $3.65 \pm 0.03 \mu \mathrm{M}$, which is $35 \%$ of the maximal activation mediated by Rosi. In consequence, we classified this ligand as a partial agonist and did not include it on our further biological and structural characterizations. In addition, we also investigated the isotype selectivity of AM-879, P11, and R32. Interestingly, none of them activated other PPAR isotypes (PPAR $\alpha$ and PPAR $\beta$ ), in comparison to their full agonists (Figure S3 in Supplementary Material). In conclusion, R32 seems to be a partial agonist because it slightly but significantly activates PPAR $\gamma$, whereas AM-879 and P11 are not able to activate any PPARs in 293T cells. For this reason, we decided to include only AM-879 and P11 in further biological and structural characterization studies.

\section{AM-879 Differs from P11 in Its Ability to Recruit a Corepressor}

We next investigated the influence of AM-879 and P11 on the recruitment of coregulators by PPAR $\gamma$. For this, we performed in vitro binding assays using fluorescence anisotropy to measure PPAR $\gamma$ affinities for coactivator (TRAP SRC2) or corepressor (NCOR ID2) peptides in the presence of an excess of these two ligands, with Rosi as the control.

As expected, the full agonist Rosi efficiently increased the affinity of PPAR $\gamma$ for the TRAP coactivator peptide (Kd of $0.040 \pm 0.005 \mu \mathrm{M})$ in comparison to the apo form ( $\mathrm{Kd}$ of $0.24 \pm 0.01 \mu \mathrm{M})$. In turn, the Kd in the presence of AM-879 and P11 was close to that measured for apo-PPAR $\gamma(0.19 \pm 0.02$ and $0.34 \pm 0.05 \mu \mathrm{M}$, respectively, Figure 4A), indicating a more similar behavior to the unbound receptor. This experiment showed 
<smiles></smiles><smiles>O=C(O)c1ccc(/C=C/C(=O)c2ccc3ccccc3c2)cc1</smiles><smiles>[R10]C=CC(=O)c1cccc([N+](=O)[O-])c1</smiles>

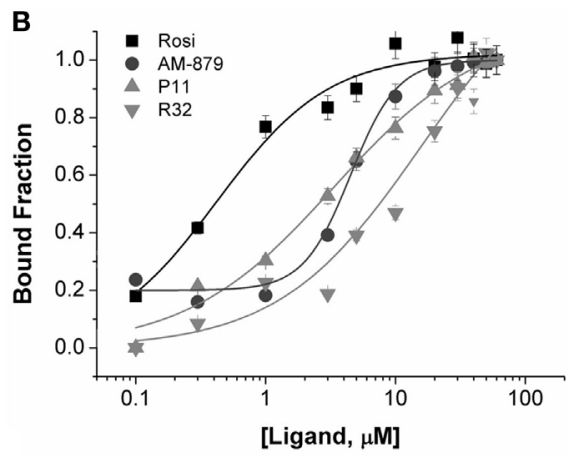

C

\begin{tabular}{cc}
\hline Ligand & Kd $(\boldsymbol{\mu M})$ \\
\hline Rosiglitazone & $0.4 \pm 0.1$ \\
AM-879 & $4.5 \pm 0.6$ \\
P11 & $3.3 \pm 0.7$ \\
R32 & $15.7 \pm 2.7$ \\
\hline
\end{tabular}

FIGURE 2 | Binding affinity of AM-879, P11, and R32 ligands to peroxisome proliferator-activated receptor gamma (PPAR $\gamma$ ) ligand-binding domain (LBD). (A) Molecular structure of the selected ligands. (B) PPAR $\gamma$ LBD bound to increased concentrations of Rosiglitazone (Rosi), AM-879, P11, and R32 (until $60 \mu \mathrm{M}$ ). Bound fractions were determined from 8-Anilino-1-naphthalenesulfonic acid (ANS) fluorescence signal decayment at 340 nm, as a result of ANS probe displacement from PPAR $\gamma$ pocket, and normalized from 0 to 1. Data are the mean \pm SEM $(n=3)$. (C) Dissociation constants $(K d$, in $\mu M)$ calculated from ligand-binding curves fitted through Hill model using Origin.

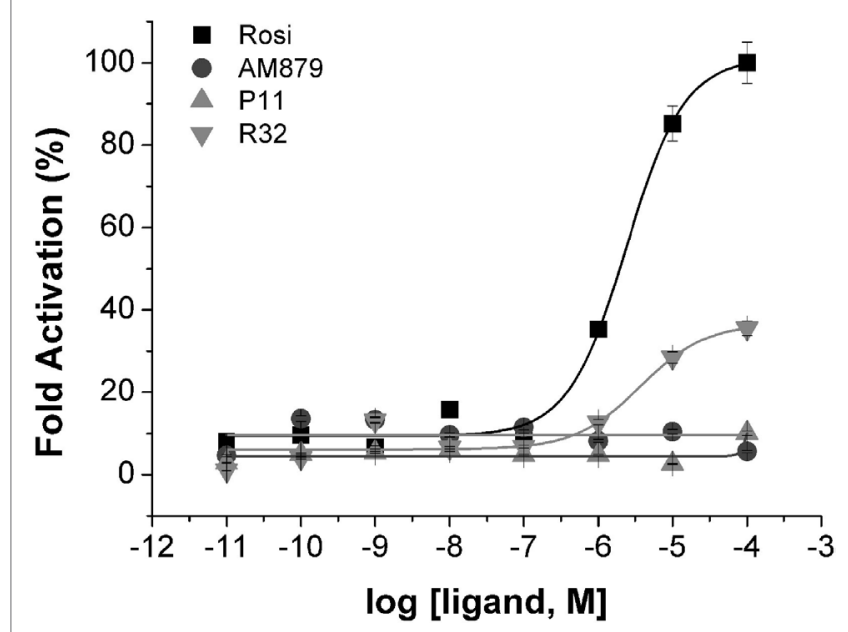

FIGURE 3 | Peroxisome proliferator-activated receptor gamma (PPAR $\gamma$ ) transactivation assay in the presence of the three selected ligands in 293T cells using a GAL4-PPAR $\gamma$-LBD reporter gene. Concentration-effect curves were measured for AM-879 (circles), P11 (triangles), and R32 (inverted triangles) ligands. Rosiglitazone (Rosi, squares) was used as positive control. Ligand concentration varied from $0.01 \mathrm{nM}$ to $0.1 \mathrm{mM}$ and the response was presented as fold activation, normalized against the maximal luciferase induction produced by Rosi. Data are the mean $\pm \operatorname{SEM}(n=3)$.

that AM-879 does not favor coactivator recruitment, whereas P11 only slightly induced coactivator recruitment.

Rosiglitazone strongly decreased the affinity of PPAR $\gamma$ for the NCOR corepressor peptide (Kd of $20.0 \pm 2.3 \mu \mathrm{M})$ compared with the apo form ( $\mathrm{Kd}$ of $0.61 \pm 0.07 \mu \mathrm{M})$ (Figure 4B), as expected for a full agonist. By contrast, the presence of AM-879 did not induce any release of the NCOR peptide; the Kd value measured in this condition was in the same range as that measured for the apo form (Kd of $1.9 \pm 0.2 \mu \mathrm{M}$ ) (Figure 4B). In the presence of $\mathrm{P} 11$, the interaction between PPAR $\gamma$ and the corepressor peptide lowered to reach a $\mathrm{Kd}$ of $8.7 \pm 1.1 \mu \mathrm{M}$. This suggests that although ligand P11 did not activate the receptor, it is not a good enough ligand to keep PPAR $\gamma$ in the repressed state. Thus, we identified two PPAR $\gamma$ ligands that did not activate the receptor and did not promote coactivator binding. However, P11 failed to maintain PPAR $\gamma$ bound to the corepressor, and, thus, we decided not to further characterize this ligand. Interestingly, despite AM-879 having already been described as PPAR $\gamma$ ligand (29), we found that it is not able to induce coactivator recruitment or corepressor release from PPAR $\gamma$. For this reason, we chose to further characterize the mechanism of action of AM-879, in terms of adipocyte differentiation, PPAR $\gamma$ Ser273 phosphorylation, and gene expression.

\section{AM-879 Does Not Induce Adipocyte Differentiation and Induces a Different Profile of Gene Expression in 3T3-L1 Cells Compared with That Induced by Rosi}

We next investigated the action of AM-879 on endogenous genes by studying its ability to induce adipogenesis, a well-characterized PPAR $\gamma$-regulated function (39).

3T3-L1 preadipocytes treated with dexamethasone were able to differentiate into adipocytes (Figure 5A) and, as expected, the addition of the full PPAR $\gamma$ agonist Rosi strongly induced adipogenesis, as evidenced by oil red $\mathrm{O}$ staining (Figures 5A,B). In contrast to Rosi, ligand AM-879 did not induce a significant 

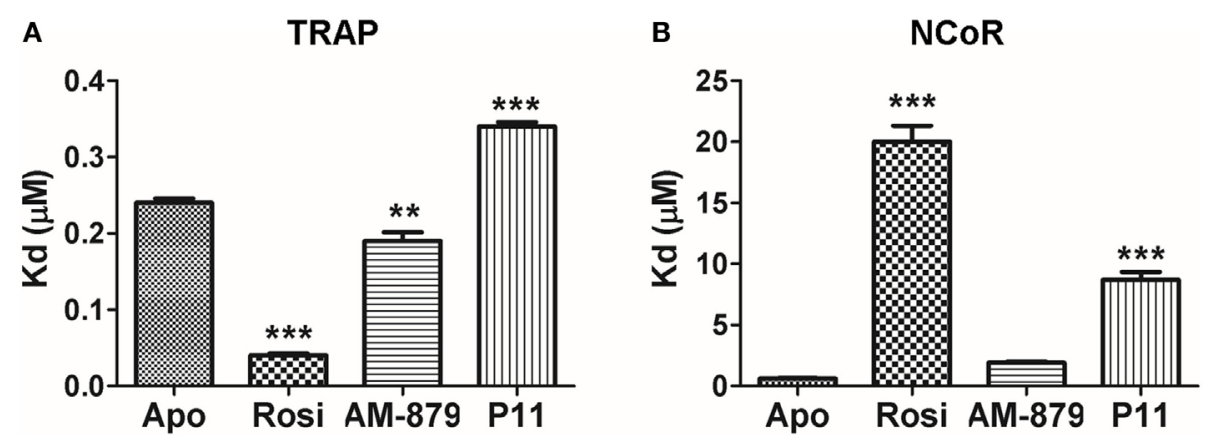

FIGURE 4 | In vitro recruitment of coregulators by peroxisome proliferator-activated receptor gamma (PPAR $\gamma$ ) in the presence of AM-879 and P11. (A) Dissociation constants (Kds, $\mu \mathrm{M}$ ) between PPAR ligand-binding domain (LBD) and TRAP coactivator peptide in the absence (Apo) or in the presence of the ligands Rosiglitazone (Rosi), AM-879 and P11. (B) Kd ( $\mu$ M) between PPAR $\mathrm{LBD}$ and NCoR corepressor peptide in the absence (Apo) or in the presence of ligands. Kds were determined from ligand-binding curves (until $20 \mu \mathrm{M}$ ), obtained by fluorescence anisotropy measurements using fluorescein labeled TRAP (ID2) or NCoR (ID2) peptides $(20 \mathrm{nM})$. Data are the mean $\pm \operatorname{SEM}\left(n=3,{ }^{\star \star} p<0.05,{ }^{\star \star *} p<0.001 \mathrm{vs} \mathrm{Apo}\right)$

A

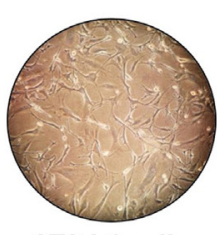

3T3-L1 cells

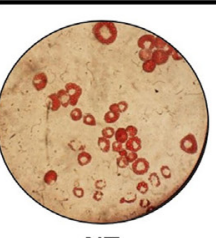

NT

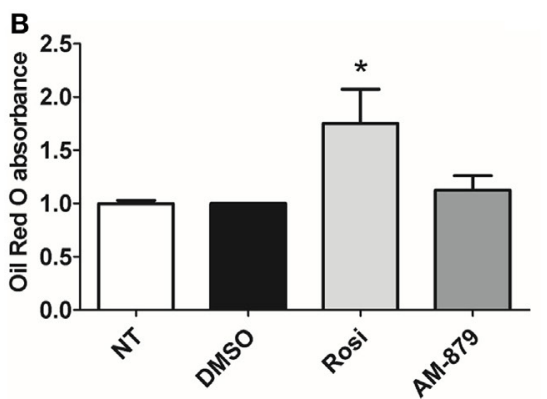

+ Dexamethasone $1 \mathrm{mM}$

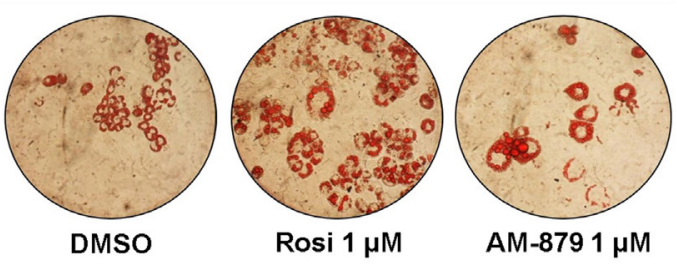

C

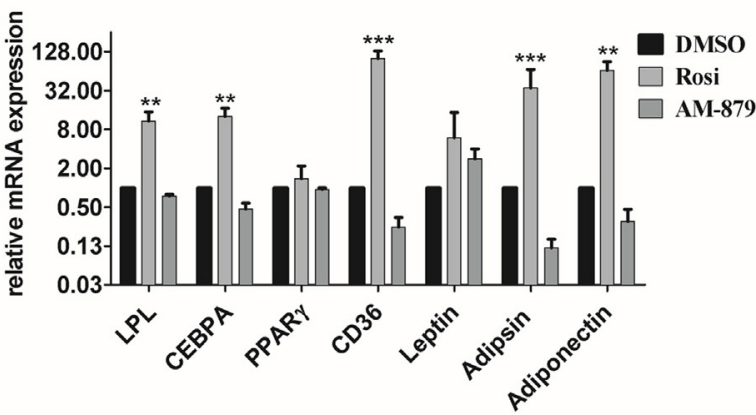

FIGURE 5 | Effects of AM-879 on adipocyte differentiation and gene expression. (A) Representative images (400x) of lipid accumulation by Oil Red O staining in 3T3-L1 differentiated cells under different conditions. Images were obtained in random fields of three independent experiments performed in duplicates.

(B) Quantification of lipid accumulation by Oil Red O absorbance measurement at $520 \mathrm{~nm}$ in not-treated 3T3-L1 differentiation cells, or in cells treated with dimethyl sulfoxide (DMSO) (control, 5\%), Rosiglitazone (Rosi, $1 \mu \mathrm{M})$, or AM-879 (1 $\mu \mathrm{M})$. Data were normalized by DMSO absorbance. (C) RT-qPCR analysis of $L P L$, CEBPA, PPARr, CD36, Leptin, Adipsin, and Adiponectin expression levels in differentiated 3T3-L1 cells treated with $1 \mu \mathrm{M}$ Rosi, $1 \mu \mathrm{M}$ AM-879, or $1 \%$ DMSO (control). Data are the mean $\pm \operatorname{SEM}\left(n=3\right.$ independent replicates, ${ }^{\star} p<0.05,{ }^{* \star} p<0.01,{ }^{\star \star *} p<0.001$ vs DMSO).

increase in adipocyte differentiation or lipid accumulation $(1.12 \pm 0.13$-fold) in comparison with DMSO (Figures 5A,B).

Moreover, the effect of AM-879 on adipocyte differentiation was further studied by examining the endogenous expression of a number of PPAR $\gamma$ target genes, namely $L P L$ (lipoprotein lipase), Cebpa, Pparg (PPAR $\gamma$ ) itself, Cd36, Lep (Leptin), Cfd (Adipsin), and Adipoq (Adiponectin), in 3T3-L1 cells. Cells treated with AM-879 presented slightly reduced levels of $C f d$, Adipoq, and Cd36 expression, in comparison to the negative control (DMSO), while Rosi strongly increased the relative expression of these genes. By contrast, AM-879 did not alter the relative expression levels of
Pparg, Lep, Cebpa, and Lpl (Figure 5C). These results showed that AM-879 induce a different change in the gene expression profile compared with that induced by Rosi.

\section{AM-879 Reduced PPAR $\gamma$ Phosphorylation Induced by CDK5}

AM-879 did not activate PPAR $\gamma$; therefore, we investigate if it was capable of interfering with PPAR $\gamma$ phosphorylation at Ser 273. The inhibition of CDK5-mediated phosphorylation of PPAR $\gamma$ is a well-known antidiabetic mechanism produced by drugs, such as Rosi (6). 
Using a luminescent ADP detection assay, we detected the ADP produced by CDK5-mediated phosphorylation of PPAR $\gamma$. As expected, preincubation of Rosi with PPAR $\gamma$ decreased the phosphorylation of this receptor by $22 \%$ (Figure 6). Interestingly, ligand AM-879 was more effective (28\%) at reducing the phosphorylation of Ser 273 induced by CDK5 compared with Rosi. Thus, in addition to being a non-agonist of PPAR $\gamma$, ligand AM-879 is a more efficient inhibitor of CDK5-induced PPAR $\gamma$ phosphorylation; therefore, AM-879 may promote insulin sensitization.

\section{Crystal Structure of the PPAR $\gamma: A M-879$ Complex Supports Its Non-Agonist Activity of AM-879}

Finally, we solved the crystal structure of PPAR $\gamma$ LBD bound to AM-879 to reveal the mechanism by which this compound binds to PPAR $\gamma$ without inducing its activation. The 2.7 íresolution structure of the complex between PPAR $\gamma$ and AM-879 derived from co-crystals reveals the canonical fold of the agonist conformation of nuclear receptor LBDs (40) (Figure 7A; Table S3 in Supplementary Material). In fact, the structure is nearly identical to that of PPAR $\gamma$ in complex with Rosi (PDB code 2PRG) (41), with a root-mean-square deviation value of $0.422 \mathrm{~A}$, calculated for $216 \mathrm{C} \alpha$ atoms. The most striking changes were in the loop between helices $\mathrm{H} 2$ and $\mathrm{H} 3$. The electron density corresponding to AM-879 is rather poorly defined, but many trials of co-crystallization with different excesses of ligand and of soaking did not produce a better density for the ligand. However, the calculation of a Polder map (34) and its statistical analysis (0.6772 for the calculated Fobs (observed $F$ value) with the ligand compared to

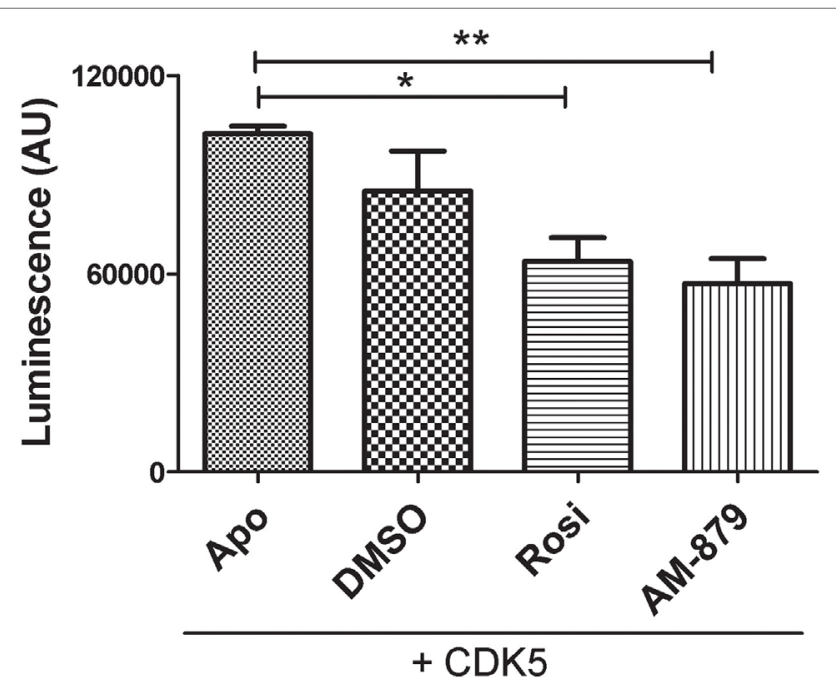

FIGURE 6 | In vitro inhibition of cyclin-dependent kinase 5 (CDK5)-mediated phosphorylation of peroxisome proliferator-activated receptor gamma (PPAR $\gamma$ ) by AM-879. Luminescence signal detected as consequence of ADP production in in vitro phosphorylation reaction containing CDK5/p35 kinase, ATP and PPAR $\gamma$ ligand-binding domain (ADP-GloTM Kinase assay). Reactions were conducted in the absence (Apo) or the presence of threefold excess of Rosiglitazone (Rosi), AM-879 or dimethyl sulfoxide (DMSO). Data are the mean $\pm \operatorname{SEM}\left(n=3,{ }^{*} p<0.05,{ }^{* *} p<0.01\right.$, vs Apo $)$.
0.3777 for the calculated Fobs without the ligand) supported the view that the ligand is present in the $\beta$-sheet sub-pocket of PPAR $\gamma$ and extends between C285 and M364 (Figure 7B). The electron density map presents three regions in which we could fit the ligand in different orientations. One model of the complex could be calculated with two alternative conformations of the ligand (Figure 7B), with reasonable statistically significant differences $(\mathrm{R} / \mathrm{Rfree}=22.8 \% / 28.7 \%)$. However, with these data, we cannot determine whether the models result from truly different ligand conformations or involve the unique placement of the ligand in one conformation.

Based on existing PPAR $\gamma$ complex structures, it has been suggested that full agonists, such as Rosi, occupy both the H12 and $\beta$-sheet sub-pockets, establishing hydrogen bonds with residues Y473 (H12), on the one side, and S342 (S1/S2), on the other side, whereas partial agonists or non-agonists would bind essentially to the $\beta$-sheet sub-pocket (42). Our ligand AM-879 occupied the $\beta$-sheet sub-pocket establishing a contact with S342 and only a small part of the H12 sub-pocket, with no direct interaction with $\mathrm{H} 12$; these interactions are in accordance with its non-agonist properties. In addition, the limited number of hydrogen bonds and van der Walls interactions established with PPAR $\gamma$ residues could account for the low affinity of this ligand for the protein (Figure 7C). Thus, the poorly defined density of the ligand suggests a dynamic behavior of this compound, which is not well stabilized in the LBP.

\section{DISCUSSION}

In this study, we developed a new approach to screen for PPAR $\gamma$ ligands following a pipeline of assays that consider the biophysical characteristics of this nuclear receptor, aiming to identify ligands that bind to the receptor but do not promote coactivator recruitment, phosphorylation of S273, and adipogenic activity. Based on this, we first identified three hit compounds (AM-879, P11, and R32) with partial or non-agonist properties on PPAR $\gamma$. Moreover, we characterize one of them deeply, compound AM-879, as a promising PPAR $\gamma$ non-agonist. Despite the fact that this ligand was previously described (29), our results showed, for the first time, that AM-879 could inhibit CDK5-mediated PPAR $\gamma$ phosphorylation and did not exhibit adipogenic effects; both these observations were supported by the analysis of the PPAR $\gamma: A M-879$ co-crystal structure.

From an initial library of 80 compounds, our screening selected three of them because of their ability to stabilize the receptor and bind to the PPAR $\gamma$ hydrophobic pocket. Among the 20 compounds that efficiently stabilized the PPAR $\gamma$ structure (Figure 1), 17 compounds, including the one that induced the highest Tm of PPAR $\gamma$ in TSA assay, were not able to significantly displace the ANS probe in the second step of screening (Figure S2 in Supplementary Material). This evidence suggests that, despite TSA being a primary filter for ligand screening, it is strongly recommended to run a secondary assay, whose objective is finding ligands that interact with the LBP of the protein.

In addition, there are questions surrounding the application of TSA as the best screening assay to find PPAR $\gamma$ ligands. First, it was reported (29) that PPAR $\gamma$ TSA produces, in some 

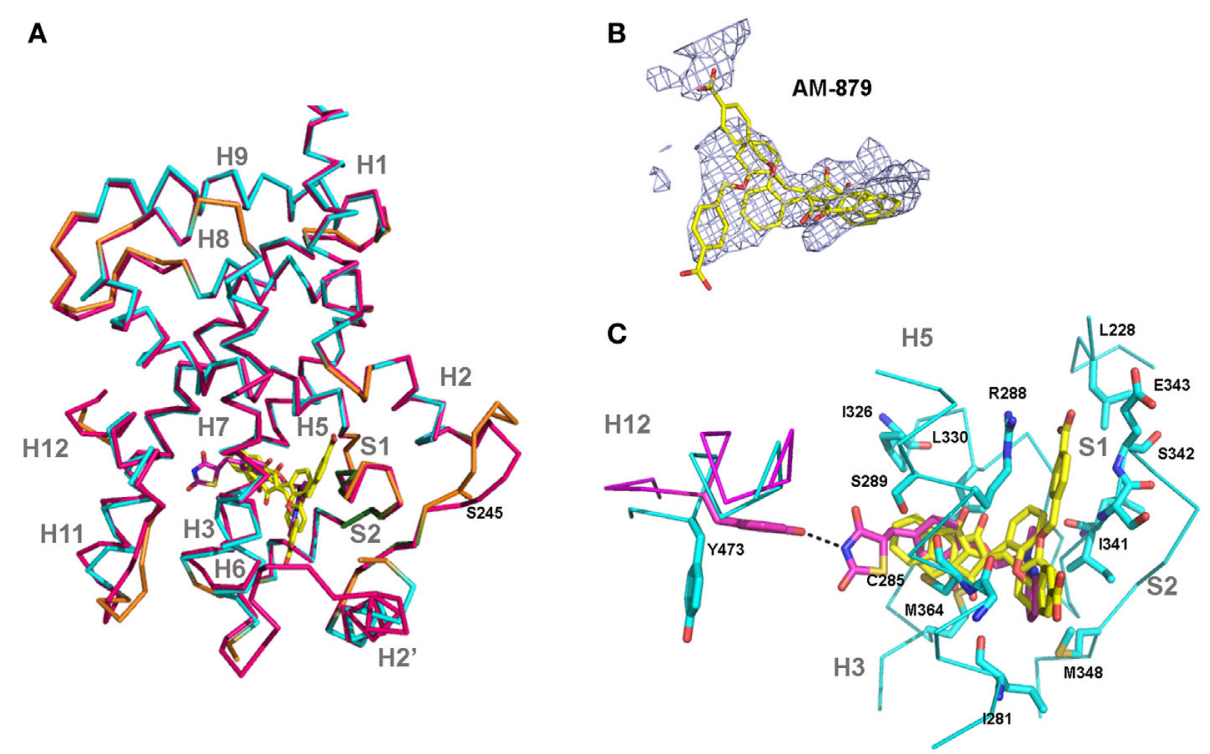

FIGURE 7 | Crystal structure of peroxisome proliferator-activated receptor gamma (PPARy)-ligand-binding domain (LBD) in complex with AM-879. (A) Superimposition of the co-crystal structure of PPAR $\gamma$-LBD bound to AM-879 on the structure with Rosiglitazone (Rosi; PDB code 2PRG). Carbon atoms are shown in cyan (alpha helix), green (beta-sheet), and orange (loop) in the AM-879 complex, and in pink, in the Rosi structure. The ligands are shown in stick representation with carbon colored yellow or pink, respectively, for AM-879 and Rosi and the serine S273, site of phosphorylation by cyclin-dependent kinase 5 (CDK5), is shown as orange sticks. (B) AM-879 in the Polder map contoured at 3.0 \%. (C) PPAR $\gamma$ residues (shown as blue sticks) in contact with AM-879. Highlight for Tyrosine 473 (pink sticks) important for the Rosi binding and agonism. Residues number corresponds to PPAR 1 isoform.

cases, Tm values similar for both the bound and unbound state of the receptor; this could lead to misinterpretation of data. Furthermore, it was noted that the difference between the Tms of the apo and compound-bound forms of PPAR $\gamma$ could not be estimated correctly due to the presence of free FAs from bacteria inside the LBP (43) of the receptor and, consequently, the actual Tm for apo-PPAR $\gamma$ could be lower than the measured value. To avoid these issues, we confirmed our TSA results using nanoDSF as a more accurate technique to quantify the thermal stability of the protein. The nanoDSF results confirmed the TSA structural stabilization profile and maintained the same order for AM-879, P11, and R32 (Table S1 in Supplementary Material), even though the Tm values in the second analysis were more clearly defined. Interestingly, using nanoDSF, the difference between the Tms of apo-PPAR $\gamma$ and PPAR $\gamma$ in the presence of Rosi increased from $1^{\circ} \mathrm{C}$ to more than $2{ }^{\circ} \mathrm{C}$, improving the reliability of the analysis. A possible explanation for this difference is that, in contrast to TSA, which depends on an extrinsic fluorescent dye, nanoDSF measures the intrinsic fluorescence of tryptophan. The use of intrinsic fluorescence avoids, for example, possible undesirable stabilization of the unfolded protein state by the dye used in TSA or by solubilizing agents, such as DMSO (44).

The ANS external probe assay was applied as the second step in our screening pipeline. This technique is a simpler and cheaper solution to identify compounds that successfully compete with the hydrophobic probe in the PPAR $\gamma$ pocket (30). Using this assay, we determined the Kds for the three identified PPAR $\gamma$ ligands (Figure 2). Moreover, based on this assay, we discarded those TSA pre-selected compounds that presented very low affinity for the receptor. In other words, the ANS assay allowed us to reduce the number of compounds in our screening, and indirectly quantified the affinities between PPAR $\gamma$ and the identified ligands. Our results showed that Rosi presented the lowest Kd value. Moreover, R32 presented the lowest affinity for PPAR $\gamma$ among three pre-selected compounds, and P11 and AM-879 showed similar intermediate Kd values.

Another checkpoint of our screening pipeline was the PPAR $\gamma$ cell-based transactivation assay. Interestingly, in this assay, AM-879 and P11 did not present any significant change in PPAR $\gamma$ activation, even at the highest concentration of $0.1 \mathrm{mM}$ (Figure 3), acting as non-agonist ligands. By contrast, R32 activated the receptor at higher concentrations with a submaximal effect compared with activation by the full agonist Rosi; this observation supported the partial agonist activity of this ligand (45). Thus, although AM-879 and P11 have higher affinities for PPAR $\gamma$ compared with R32, they were not able to activate the receptor, which confirmed the relative lack of agonistic properties of these ligands.

Based on this three-step screening, we identified three PPAR $\gamma$ ligands and performed an initial characterization of them, which allowed us to classify them as two non-agonists and one partial agonist. Our objective was to find PPAR $\gamma$ ligands capable of binding to the receptor without promoting any kind of agonism; therefore, we discarded ligand R32 and only further characterized AM-879 and P11. Another piece of evidence that confirmed the efficiency of our screening approach was the identification of AM-879 as a PPAR $\gamma$ ligand. As mentioned before, this same ligand was previously described as a possible PPAR $\gamma$ antagonist, because it reduced the activation of the receptor (29). However, 
in our assays, we observed a non-agonist action because the basal activation of PPAR $\gamma$ was not changed in the presence of this molecule; for this reason, we further investigated this compound.

Our post-screening characterization of AM-879 and P11, through coregulator recruitment experiments, supported the transactivation assay results. Both ligands have a reduced ability to induce TRAP coactivator recruitment, suggesting that they induce a PPAR $\gamma$ conformation closer to the apo form compared with the Rosi-bound form. In addition, PPAR $\gamma$ in presence of AM-879 presented an affinity for NCOR that was statistically no different to that of the PPAR $\gamma$ apo form (Figure 4B), suggesting that this ligand is not able to displace the NCOR corepressor, maintaining the receptor in a repressed state. In the case of P11, despite its lack of induction of coactivator recruitment, it did not maintain the receptor in the repressed state. For this reason, P11 was discarded. The repressed state is very interesting in terms of finding a promising PPAR $\gamma$ modulator with no obesogenic properties. For this reason, we investigated if the biological effects of AM-879 were related to the effects of classical activation of $\operatorname{PPAR} \gamma$, such as adipogenesis, which had not been previously evaluated.

Evidence from adipocyte differentiation assays showed that AM-879 cannot induce differentiation of 3T3-L1 cells into adipocytes (Figures 5A,B). The maintenance of differentiation levels similar to those of the control, together with transactivation and coregulator recruitment results, strongly suggested the non-agonistic activity of this ligand. In addition, in this cell strain, the previously suggested possible PPAR $\gamma$ antagonist activity of AM-879 (29) was not confirmed since this ligand did not present any significant reduction in adipocyte differentiation compared with untreated control cells, which is a well-described characteristic of antagonists, such as BADGE (46) and GW9662 (47). Interestingly, the inability of AM-879 to induce adipogenesis is actually a desirable characteristic of PPAR $\gamma$ ligands endowed with antidiabetic properties, and may be explained by the relationship between adipogenesis and weight gain produced by TZDs drugs $(6,21,39,48,49)$.

In the context of adipogenesis, AM-879 did not induce the expression of the adipogenic markers genes, Cebpa and Cd36 (50, 51), in 3T3-L1 cells, which contrasted with the effect of the full PPAR $\gamma$ agonist, Rosi, which, as expected, strongly increased the expression of these genes $(9,45,52)$. Cells treated with AM-879 present similar levels of mRNA, in comparison to control cells, for the key regulator of adipogenesis CEBPA, which together with $\operatorname{PPAR} \gamma$, is essential during the early stage of adipocyte differentiation (53), and in the maintenance of this state (54,55). Cd36, another important gene in lipid metabolism that is also a direct target of PPAR $\gamma$ (56), showed slightly reduced mRNA expression after AM-879 treatment. This gene encodes the FA translocase (FAT/CD36) protein, which plays major roles in the transport of long-chain FAs (57). Thus, the data suggested that the decrease in Cd36 levels produced in response to the ligand might limit the FA influx into adipocytes.

Surprisingly, the expression of the genes encoding adipsin and adiponectin, which are targets of selective modulation by putative antidiabetic ligands, such as L312 (58) and F12016 (52), was also reduced by AM-879 treatment (Figure 5C). It is unclear whether this effect is a consequence of the competition with endogenous PPAR $\gamma$ agonists, such as FAs, leading to possible reduction in PPAR $\gamma$ activation or a consequence of the modulation of other pathways. In the latter case, the CD36 and adiponectin regulation pathways, for example, may be associated, and a decrease in the CD36 level might interfere with the expression of adiponectin (59). In general, these findings showed a tendency of AM-879 to reduce adipogenesis at the genomic level, which agrees with its inability to induce differentiation of 3T3-L1 cells.

As previously demonstrated (6), the insulin-sensitizing effects produced by TZDs are not primarily associated with PPAR $\gamma$ agonism. In fact, the activation of the receptor per se, when it induces, for example, adipogenesis, is a putative cause of PPAR $\gamma$ modulated adverse effects. In this context, phosphorylation of the serine residue S273 in PPAR $\gamma$ LBD was identified as a link between obesity and insulin resistance, and its inhibition by PPAR $\gamma$ ligands, such as TZDs, was directly related to their antidiabetic effects. Interestingly, in addition to the inability of AM-879 to activate PPAR $\gamma$, this compound also inhibited S273 phosphorylation in vitro, suggesting the antidiabetic potential of this ligand; the antidiabetic potential of this ligand may be higher than that of Rosi.

In accordance with these findings, and as demonstrated for other ligands that block phosphorylation $(6,9)$, our solved crystal structure of PPAR $\gamma / \mathrm{AM}-879$ established that the ligand makes most of these contacts in the $\beta$-sheet region of the LBP. In addition, the proximity of this ligand to the amide of S342, in one of its conformations, probably accounts for its capacity to inhibit phosphorylation, because it was reported that the association between the potency of S273 phosphorylation blockage by ligands and the strength of a ligand interaction with S342 amide backbone induces helix 2-helix 2' loop stabilization (60). In addition, the poor definition of the electron density of the ligand in the crystal structure of the complex PPAR $\gamma$-LBD/AM- 879 may be caused by the limited affinity of this ligand for the protein or may be due to the multiple binding modes that this ligand seems to adopt in the LBP of PPAR $\gamma$. Interestingly, it has been shown that the sampling of multiple ligand-binding modes could allosterically propagate a conformational disorder to the AF2 surface of the receptor; this allosteric propagation may be sufficient to reduce or even completely block classical agonism (60).

In conclusion, we proposed a new approach to search for PPAR $\gamma$ ligands with partial or non-agonistic properties; this approach comprised a three-step pipeline. We successfully identified three PPAR $\gamma$ hit compounds among a library of $80 \mathrm{~mol}$ ecules. In addition, we were able to characterize the previously described AM-879 ligand experimentally and structurally, as a bona fide PPAR $\gamma$ non-agonist with no-adipogenic properties and with the capacity to inhibit CDK5-mediated phosphorylation of PPAR $\gamma$. Moreover, we demonstrated that AM-879 has a different gene expression regulation profile in adipocytes compared with that of the full agonist Rosi. Together with AM-879, another possible non-agonist, P11, and a partial-agonist, R32, were also identified and may be used as scaffolds for future optimization protocols that may selectively improve their affinity for the PPAR $\gamma$ binding site. 


\section{AUTHOR CONTRIBUTIONS}

Conception and design of the study: AF. Experiments and data collection: HR, NB, AB, TT, JC, FH, and AL. Data Analysis: HR, $\mathrm{AL}, \mathrm{PO}, \mathrm{FH}, \mathrm{MB}$, and NB. Drafting and critical revision of the paper: HR, AL, PO, and MB. Final Revision to be published: HR, $\mathrm{AL}$, and $\mathrm{AF}$.

\section{ACKNOWLEDGMENTS}

We thank LNBio/CNPEM for accessibility to Protein Purification Laboratory (LPP), the Spectroscopy and Calorimetry (LEC), Protein Crystallization Laboratory (ROBOLAB) and the Bioinformatics (LBI) facilities, and LNLS/CNPEM for access to Protein Crystallography Beamline (MX2). We are very grateful to Prof. Dr. R. J. Nunes and Prof. Dr. R. A. Yunes, who synthesized and gently gifted most of the ligands; to LQPN, LNbio/ CNPEM, which gifted one compound; Prof. Dr. R. A. Pilli that gently gifted 6 compounds; and Prof. Dr. A. S. Nascimento, which, initially, gently gifted some commercial compounds

\section{REFERENCES}

1. O'Neill S, O'Driscoll L. Metabolic syndrome: a closer look at the growing epidemic and its associated pathologies. Obes Rev (2014) 16(1):1-12. doi:10.1111/obr.12229

2. Kaur J. A comprehensive review on metabolic syndrome. Cardiol Res Pract (2014) 2014:1-21. doi:10.1155/2014/281483

3. Roberts CK, Hevener AL, James Barnard R. Metabolic syndrome and insulin resistance: underlying causes and modification by exercise training. Compr Physiol (2013) 3(1):1-58. doi:10.1002/cphy.c110062

4. Farmer SR. Transcriptional control of adipocyte formation. Cell Metab (2006) 4(4):263-73. doi:10.1016/j.cmet.2006.07.001

5. Anghel SI, Wahli W. Fat poetry: a kingdom for PPAR $\gamma$. Cell Res (2007) 17(6):486-511. doi:10.1038/cr.2007.48

6. Choi JH, Banks AS, Estall JL, Kajimura S, Boström P, Laznik D, et al. Antidiabetic drugs inhibit obesity-linked phosphorylation of PPARgamma by Cdk5. Nature (2010) 466(7305):451-6. doi:10.1038/nature09291

7. Deeb SS, Fajas L, Nemoto M, Pihlajamäki J, Mykkänen L, Kuusisto J, et al. A Pro12Ala substitution in PPARgamma2 associated with decreased receptor activity, lower body mass index and improved insulin sensitivity. Nat Genet (1998) 20(3):284-7. doi:10.1038/3099

8. Haas B, Schlinkert P, Mayer P, Eckstein N. Targeting adipose tissue. Diabetol Metab Syndr (2012) 4(1):43. doi:10.1186/1758-5996-4-43

9. Choi JH, Banks AS, Kamenecka TM, Busby SA, Chalmers MJ, Kumar N, et al. Antidiabetic actions of a non-agonist PPAR $\gamma$ ligand blocking Cdk5-mediated phosphorylation. Nature (2011) 477(7365):477-81. doi:10.1038/nature 10383

10. Tontonoz P, Spiegelman BM. Fat and beyond: the diverse biology of PPAR $\gamma$. Annu Rev Biochem (2008) 77(1):289-312. doi:10.1146/annurev. biochem.77.061307.091829

11. Millard CJ, Watson PJ, Fairall L, Schwabe JWR. An evolving understanding of nuclear receptor coregulator proteins. J Mol Endocrinol (2013) 51(3):T23-36. doi:10.1530/JME-13-0227

12. Siersbaek R, Nielsen R, Mandrup S. PPARgamma in adipocyte differentiation and metabolism - novel insights from genome-wide studies. FEBS Lett (2010) 584(15):3242-9. doi:10.1016/j.febslet.2010.06.010

13. Gerhold DL, Liu F, Jiang G, Li Z, Xu J, Lu M, et al. Gene expression profile of adipocyte differentiation and its regulation by peroxisome proliferator-activated receptor-gamma agonists. Endocrinology (2002) 143(6):2106-18. doi:10.1210/endo.143.6.8842

14. Kintscher U, Law RE. PPARgamma-mediated insulin sensitization: the importance of fat versus muscle. Am JPhysiol Endocrinol Metab (2005) 288(2):E287-91. doi:10.1152/ajpendo.00440.2004 to be tested in our assays. We also thank Dr. Daniel Maturana and NanoTemper Technologies to provide us technical support and devices in NanoDSF assays. Finally, we would like to thank to FAPESP, CNPq, Capes, CNPEM, and LNBio for financial support.

\section{FUNDING}

This work was supported by the "Fundação de Amparo à Pesquisa do Estado de São Paulo" (FAPESP; grant number 2016/22246-0 and 2013/26507-4), "Conselho Nacional de Desenvolvimento Científico e Tecnológico" (CNPq; grant number 480254/20125) and "Coordenação de Aperfeiçoamento de Pessoal de Nível Superior" (CAPES; grant number 23038.006737/2012-56).

\section{SUPPLEMENTARY MATERIAL}

The Supplementary Material for this article can be found online at http://www.frontiersin.org/articles/10.3389/fendo.2018.00011/ full\#supplementary-material.

15. Leonardini A, Laviola L, Perrini S, Natalicchio A, Giorgino F. Cross-talk between PPARgamma and insulin signaling and modulation of insulin sensitivity. PPAR Res (2009) 2009:818945. doi:10.1155/2009/818945

16. Lebovitz HE. Rationale for and role of thiazolidinediones in type 2 diabetes mellitus. Am J Cardiol (2002) 90(5):34-41. doi:10.1016/S0002-9149(02) 02557-2

17. Soccio RE, Chen ER, Lazar MA. Thiazolidinediones and the promise of insulin sensitization in type 2 diabetes. Cell Metab (2014) 20(4):573-91. doi:10.1016/j. cmet.2014.08.005

18. Saltiel AR, Olefsky JM. Thiazolidinediones in the treatment of insulin resistance and type II diabetes. Diabetes (1996) 45(12):1661-9. doi:10.2337/ diabetes.45.12.1661

19. Nissen SE, Wolski K. Effect of rosiglitazone on the risk of myocardial infarction and death from cardiovascular causes. N Engl J Med (2007) 356(24):2457-71. doi:10.1056/NEJMoa072761

20. Oakes ND, Thalén PG, Jacinto SM, Ljung B. Thiazolidinediones increase plasma-adipose tissue FFA exchange capacity and enhance insulin-mediated control of systemic FFA availability. Diabetes (2001) 50(5):1158-65. doi:10.2337/diabetes.50.5.1158

21. Ye J-M, Dzamko N, Cleasby ME, Hegarty BD, Furler SM, Cooney GJ, et al. Direct demonstration of lipid sequestration as a mechanism by which rosiglitazone prevents fatty-acid-induced insulin resistance in the rat: comparison with metformin. Diabetologia (2004) 47(7):1306-13. doi:10.1007/ s00125-004-1436-1

22. Sharma AM, Staels B. Review: peroxisome proliferator-activated receptor gamma and adipose tissue - understanding obesity-related changes in regulation of lipid and glucose metabolism. J Clin Endocrinol Metab (2007) 92(2):386-95. doi:10.1210/jc.2006-1268

23. Nagai H, Ebisu S, Abe R, Goto T, Takahashi N, Hosaka T, et al. Development of a novel PPAR $\gamma$ ligand screening system using pinpoint fluorescence-probed protein. Biosci Biotechnol Biochem (2011) 75(2):337-41. doi:10.1271/ bbb. 100810

24. Markt P, Petersen RK, Flindt EN, Kristiansen K, Kirchmair J, Spitzer G, et al Discovery of novel PPAR ligands by a virtual screening approach based on pharmacophore modeling, 3D shape, and electrostatic similarity screening. J Med Chem (2008) 51(20):6303-17. doi:10.1021/jm800128k

25. Markt P, Schuster D, Kirchmair J, Laggner C, Langer T. Pharmacophore modeling and parallel screening for PPAR ligands. J Comput Aided Mol Des (2007) 21(10-11):575-90. doi:10.1007/s10822-007-9140-0

26. Ma J-J, Zhang T, Fang N, Zou Y, Gong Q-H, Yu L-M, et al. Establishment of a cell-based drug screening model for identifying agonists of human peroxisome proliferator-activated receptor gamma (PPAR $\gamma)$. J Pharm Pharmacol (2012) 64(5):719-26. doi:10.1111/j.2042-7158.2012.01462.x 
27. Gao D, Zhang Y, Yang F, Lin Y, Zhang Q, Xia Z. In vitro screening and evaluation of 37 traditional Chinese medicines for their potential to activate peroxisome proliferator-activated receptors- $\gamma$. Pharmacogn Mag (2016) 12(46):120-7. doi:10.4103/0973-1296.177909

28. El-Houri RB, Mortier J, Murgueitio MS, Wolber G, Christensen LP. Identification of PPAR $\gamma$ agonists from natural sources using different in silico approaches. Planta Med (2015) 81(6):488-94. doi:10.1055/s-0034-1383119

29. da Silva FMC, dos Santos JC, Campos JLO, Mafud AC, Polikarpov I, Figueira ACM, et al. Structure-based identification of novel PPAR gamma ligands. Bioorg Med Chem Lett (2013) 23(21):5795-802. doi:10.1016/j.bmcl.2013.09.010

30. Zorrilla S, Garzón B, Pérez-Sala D. Selective binding of the fluorescent dye 1-anilinonaphthalene-8-sulfonic acid to peroxisome proliferator-activated receptor $\gamma$ allows ligand identification and characterization. Anal Biochem (2010) 399(1):84-92. doi:10.1016/j.ab.2009.12.021

31. Riu A, Grimaldi M, le Maire A, Bey G, Phillips K, Boulahtouf A, et al. Peroxisome proliferator-activated receptor $\gamma$ is a target for halogenated analogs of bisphenol A. Environ Health Perspect (2011) 119(9):1227-32. doi:10.1289/ehp.1003328

32. Kabsch W. XDS. Acta Crystallogr D Biol Crystallogr (2010) 66(Pt 2):125-32. doi:10.1107/S0907444909047337

33. Riu A, le Maire A, Grimaldi M, Audebert M, Hillenweck A, Bourguet W, et al. Characterization of novel ligands of $\operatorname{ER} \alpha, \operatorname{Er} \beta$, and PPAR $\gamma$ : the case of halogenated bisphenol A and their conjugated metabolites. Toxicol Sci (2011) 122(2):372-82. doi:10.1093/toxsci/kfr132

34. Liebschner D, Afonine PV, Moriarty NW, Poon BK, Sobolev OV, Terwilliger TC, et al. Polder maps: improving OMIT maps by excluding bulk solvent. Acta Crystallogr D Struct Biol (2017) 73(Pt 2):148-57. doi:10.1107/ S2059798316018210

35. Emsley P, Cowtan K. Coot: model-building tools for molecular graphics. Acta Crystallogr D Biol Crystallogr (2004) 60(Pt 12 Pt 1):2126-32. doi:10.1107/ S0907444904019158

36. Adams PD, Afonine PV, Bunkóczi G. PHENIX: A comprehensive Pythonbased system for macromolecular structure solution. Acta Crystallogr Sect D Biol Crystallogr (2010) 66(2):213-21. doi:10.1107/S0907444909052925

37. Hamuro Y, Coales SJ, Morrow JA, Molnar KS, Tuske SJ, Southern MR, et al. Hydrogen/deuterium-exchange (H/D-Ex) of PPAR $\gamma$ LBD in the presence of various modulators. Protein Sci (2006) 15(8):1883-92. doi:10.1110/ps.062103006

38. Amato AA, Rajagopalan S, Lin JZ, Carvalho BM, Figueira ACM, Lu J, et al. GQ-16, a novel peroxisome proliferator-activated receptor $\gamma(\operatorname{PPAR} \gamma)$ ligand, promotes insulin sensitization without weight gain. JBiol Chem (2012) 287(33):28169-79. doi:10.1074/jbc.M111.332106

39. Nesto RW, Bell D, Bonow RO, Fonseca V, Grundy SM, Horton ES, et al. Thiazolidinedione use, fluid retention, and congestive heart failure: a consensus statement from the American Heart Association and American Diabetes Association. Circulation (2003) 108(23):2941-8. doi:10.1161/01. CIR.0000103683.99399.7E

40. Bourguet W, Germain P, Gronemeyer H. Nuclear receptor ligand-binding domains: three-dimensional structures, molecular interactions and pharmacological implications. Trends Pharmacol Sci (2000) 21(10):381-8. doi:10.1016/S0165-6147(00)01548-0

41. Nolte RT, Wisely GB, Westin S, Cobb JE, Lambert MH, Kurokawa R, et al. Ligand binding and co-activator assembly of the peroxisome proliferator-activated receptor-gamma. Nature (1998) 395(6698):137-43. doi:10.1038/25931

42. Delfosse V, le Maire A, Balaguer P, Bourguet W. A structural perspective on nuclear receptors as targets of environmental compounds. Acta Pharmacol Sin (2014) 36:88-101. doi:10.1038/aps.2014.133

43. Liberato MV, Nascimento AS, Ayers SD, Lin JZ, Cvoro A, Silveira RL, et al. Medium chain fatty acids are selective peroxisome proliferator activated receptor (PPAR) $\gamma$ activators and pan-PPAR partial agonists. PLoS One (2012) 7(5):e36297. doi:10.1371/journal.pone.0036297

44. Strutz W. Exploring Protein Stability by NanoDSF. Biophys J (2016) 110(3):393a. doi:10.1016/j.bpj.2015.11.2126

45. Germain P, Staels B, Dacquet C, Spedding M, Laudet V. Overview of nomenclature of nuclear receptors. Pharmacol Rev (2006) 58(4):685-704. doi:10.1124/pr.58.4.2

46. Wright HM, Clish CB, Mikami T, Hauser S, Yanagi K, Hiramatsu R, et al. A synthetic antagonist for the peroxisome proliferator-activated receptor $\gamma$ inhibits adipocyte differentiation. J Biol Chem (2000) 275(3):1873-7. doi:10.1074/jbc.275.3.1873

47. Seargent JM, Yates EA, Gill JH. GW9662, a potent antagonist of PPARgamma, inhibits growth of breast tumour cells and promotes the anticancer effects of the PPARgamma agonist rosiglitazone, independently of PPARgamma activation. Br J Pharmacol (2004) 143(8):933-7. doi:10.1038/sj.bjp.0705973

48. Zhang F, Lavan BE, Gregoire FM. Selective modulators of PPAR-gamma activity: molecular aspects related to obesity and side-effects. PPAR Res (2007) 2007:32696. doi:10.1155/2007/32696

49. Benvenuti S, Cellai I, Luciani P, Deledda C, Baglioni S, Giuliani C, et al. Rosiglitazone stimulates adipogenesis and decreases osteoblastogenesis in human mesenchymal stem cells. J Endocrinol Invest (2007) 30(9):RC26-30. doi:10.1007/BF03350807

50. Bengestrate L, Virtue S, Campbell M, Vidal-Puig A, Hadaschik D, Hahn P, et al. Genome-wide profiling of microRNAs in adipose mesenchymal stem cell differentiation and mouse models of obesity. PLoS One (2011) 6(6):e21305. doi:10.1371/journal.pone.0021305

51. Yu S, Matsusue K, Kashireddy P, Cao W-Q, Yeldandi V, Yeldandi AV, et al. Adipocyte-specific gene expression and adipogenic steatosis in the mouse liver due to peroxisome proliferator-activated receptor gammal (PPARgamma1) overexpression. JBiol Chem (2003) 278(1):498-505. doi:10.1074/jbc. M210062200

52. Liu C, Feng T, Zhu N, Liu P, Han X, Chen M, et al. Identification of a novel selective agonist of PPAR $\gamma$ with no promotion of adipogenesis and less inhibition of osteoblastogenesis. Sci Rep (2015) 5(1):9530. doi:10.1038/srep09530

53. Linhart HG, Ishimura-Oka K, DeMayo F, Kibe T, Repka D, Poindexter B, et al. C/ EBPalpha is required for differentiation of white, but not brown, adipose tissue. Proc Natl Acad Sci U S A (2001) 98(22):12532-7. doi:10.1073/pnas.211416898

54. Sung J-H, Chon J-W, Lee M-A, Park J-K, Woo J-T, Park YK. The anti-obesity effect of Lethariella cladonioides in 3T3-L1 cells and obese mice. Nutr Res Pract (2011) 5(6):503-10. doi:10.4162/nrp.2011.5.6.503

55. Madsen MS, Siersbaek R, Boergesen M, Nielsen R, Mandrup S. Peroxisome proliferator-activated receptor $\gamma$ and $\mathrm{C} / \mathrm{EBP} \alpha$ synergistically activate key metabolic adipocyte genes by assisted loading. Mol Cell Biol (2014) 34(6):939-54. doi:10.1128/MCB.01344-13

56. Zheng W, Feng X, Qiu L, Pan Z, Wang R, Lin S, et al. Identification of the antibiotic ionomycin as an unexpected peroxisome proliferator-activated receptor $\gamma(\operatorname{PPAR} \gamma)$ ligand with a unique binding mode and effective glucose-lowering activity in a mouse model of diabetes. Diabetologia (2013) 56(2):401-11. doi:10.1007/s00125-012-2777-9

57. Yang Y, Chen M, Loux TJ, Harmon CM. Regulation of FAT/CD36 mRNA gene expression by long chain fatty acids in the differentiated 3T3-L1 cells. Pediatr Surg Int (2007) 23(7):675-83. doi:10.1007/s00383-007-1942-6

58. Xie X, Zhou X, Chen W, Long L, Li W, Yang X, et al. L312, a novel PPAR $\gamma$ ligand with potent anti-diabetic activity by selective regulation. Biochim Biophys Acta (2015) 1850(1):62-72. doi:10.1016/j.bbagen.2014.09.027

59. Hajri T, Hall AM, Jensen DR, Pietka TA, Drover VA, Tao H, et al. CD36facilitated fatty acid uptake inhibits leptin production and signaling in adipose tissue. Diabetes (2007) 56(7):1872-80. doi:10.2337/db06-1699

60. Hughes TS, Chalmers MJ, Novick S, Kuruvilla DS, Chang MR, Kamenecka TM, et al. Ligand and receptor dynamics contribute to the mechanism of graded PPAR $\gamma$ agonism. Structure (2012) 20(1):139-50. doi:10.1016/j. str.2011.10.018

Conflict of Interest Statement: The authors declare that the research was conducted in the absence of any commercial or financial relationships that could be construed as a potential conflict of interest.

Copyright (c) 2018 Ribeiro Filho, Bernardi Videira, Bridi, Tittanegro, Helena Batista, de Carvalho Pereira, de Oliveira, Bajgelman, Le Maire and Figueira. This is an open-access article distributed under the terms of the Creative Commons Attribution License (CC BY). The use, distribution or reproduction in other forums is permitted, provided the original author(s) and the copyright owner are credited and that the original publication in this journal is cited, in accordance with accepted academic practice. No use, distribution or reproduction is permitted which does not comply with these terms. 